\title{
Bat hibernacula in caves of southern Idaho: implications for monitoring and management
}

\author{
Jericho C. Whiting 1 ,*, Bill Doering ${ }^{2}$, Gary Wright ${ }^{3}$, \\ Devin K. Englestead ${ }^{4}$, Justin A. Frye ${ }^{4}$, and Todd Stefanic ${ }^{5}$ \\ ${ }^{1}$ Department of Biology, Brigham Young University-Idaho, 116 Benson Bld., Rexburg, ID 83460 \\ ${ }^{2}$ Wastren Advantage Inc., 120 Technology Drive, Idaho Falls, ID 83401 \\ ${ }^{3}$ Bureau of Land Management, 400 West F Street, Shoshone, ID 83352 \\ ${ }^{4}$ Bureau of Land Management, 1405 Hollipark Drive, Idaho Falls, ID 83401 \\ ${ }_{5}$ National Park Service, Craters of the Moon National Monument and Preserve, 1266 Craters Loop Rd., Arco, ID 83213
}

\begin{abstract}
Bat populations are being impacted by many threats, including white-nose syndrome, wind energy development, and hibernaculum disturbance and modification. Understanding the use of caves as hibernacula by bats in the western United States is necessary for the conservation and management of these mammals and their habitat, as well as for monitoring the arrival of white-nose syndrome. We identified biologically important hibernacula from 304 winter surveys (1 November-31 March) in 64 caves from 1984 to 2016 in southern Idaho, USA. During surveys researchers counted 37,693 bats representing 6 species. Townsend's big-eared bats (Corynorhinus townsendii townsendii) comprised $96.1 \%$ (36,237 individuals in 58 caves) and western small-footed myotis (Myotis ciliolabrum ssp.) comprised $3.8 \%$ (1432 individuals in 22 caves). Thirty of the 64 caves were biologically important for Townsend's bigeared bats (maximum count $\geq 20$ individuals), and the largest hibernating colony of that species occupied cave C34 (8 surveys, $\bar{x}=1610$ individuals, SD 415, range 962-1994). Thirteen caves were biologically important hibernacula for western small-footed myotis (maximum count $\geq 5$ individuals), and the largest hibernating colony of that species occupied cave C24 (6 surveys, $\bar{x}=98$ individuals, SD 53, range 32-152). Ten caves were biologically important hibernacula for both species. Our results indicate that Townsend's big-eared bats are the predominant species that hibernate on the Snake River Plain in southern Idaho, and that this area has a high density of hibernacula — and the largest reported hibernaculum - for Townsend's big-eared bats and western small-footed myotis in western North America. We recommend that biologists prioritize monitoring the 13 biologically important hibernacula of western small-footed myotis as well as the 10 caves used by both species for the potential arrival of white-nose syndrome in this area and to track the abundance of Townsend's big-eared bats. Our results will help biologists with the management and conservation of bats and their habitat as well as aid in land use planning in this area.
\end{abstract}

RESUMEN.-Las poblaciones de murciélagos están siendo afectadas por muchas amenazas, incluido el síndrome de nariz blanca, el desarrollo de energía eólica, y la alteración y modificación de los hibernaculum. Es necesario entender el uso de cuevas como hibernaculum (refugios) de los murciélagos en el oeste de los EE.UU. para la conservación y la gestión de estos mamíferos y su hábitat, así como para monitorear la posible llegada del síndrome de nariz blanca. Identificamos refugios biológicamente importantes en 304 muestreos durante el invierno (del 1 de noviembre al 31 de marzo) en 64 cuevas entre 1984 y 2016, en el sur de Idaho, EE.UU. Durante los muestreos, los investigadores contaron 37,693 murciélagos que representaron 6 especies. Los murciélagos Corynorhinus townsendii townsendii comprendieron el 96.1\% (36,237 individuos en 58 cuevas), y los murciélagos Myotis ciliolabrum ssp. comprendieron el 3.8\% (1432 individuos en 22 cuevas). Treinta de las 64 cuevas fueron biológicamente importantes (recuento máximo $\geq 20$ individuos) para Corynorhinus townsendii townsendii, y la colonia hibernante más grande de esta especie ocupaba la cueva C34 (8 muestreos, promedio = 1610 individuos, $\mathrm{DE}=415$, rango 962-1994). Trece cuevas fueron refugios biológicamente importantes (conteo máximo $\geq 5$ individuos) para Myotis ciliolabrum ssp., y la colonia hibernante más grande de esta especie ocupaba la cueva C24 $(6$ muestreos, promedio $=98$ individuos, $\mathrm{DE}=53$, rango 32-152). Diez cuevas fueron refugios biológicamente importantes para ambas especies. Nuestros resultados indican que los murciélagos Corynorhinus townsendii townsendii son las especies predominantes que hibernan en la llanura del río Snake en el sur de Idaho, y que esta área tiene una alta densidad de refugios (y el mayor refugio que se ha reportado) de murciélagos Corynorhinus townsendii townsendii y Myotis ciliolabrum ssp.en el oeste de América del Norte. Recomendamos que los biólogos den prioridad al monitoreo de los 13 refugios biológicamente importantes de Myotis ciliolabrum ssp., así como las diez cuevas utilizadas por ambas especies, debido a la posible llegada del síndrome de nariz blanca en esta área y para dar seguimiento a la abundancia de los murciélagos Corynorhinus townsendii townsendii. Nuestros resultados también pueden ayudar a los biólogos en la gestión y la conservación de los murciélagos y su hábitat, al igual que en la planificación del uso de suelo en el área.

*Corresponding author: whitingj@byui.edu 
White-nose syndrome and wind energy development—as well as human disturbance, destruction, and modification of hibernaculahave impacted bat populations. White-nose syndrome is a major threat to many bats hibernating in caves; this disease has killed at least 6.7 million bats of 7 species (Foley et al. 2011), and many species may be at risk of decline or extinction due to this disease (Knudsen et al. 2013). Recently white-nose syndrome was confirmed in the western United States (Lorch et al. 2016) and may arrive in Idaho in the next decade (Maher et al. 2012), if not sooner. Biologists in Idaho and other western states are prioritizing hibernaculum monitoring to detect the arrival of this disease. Wind energy development is expanding across the western United States accompanied by unprecedented mortality rates of bats at many facilities (Arnett et al. 2008, Cryan and Barclay 2009, Cryan 2011). Additionally, the loss, modification, and disturbance of hibernacula by humans have long been concerns for the conservation of bats (Sheffield et al. 1992, Adams 2003, Gruver and Keinath 2006). These threats make it essential to identify important hibernacula for the conservation and management of bats and their habitat (Olson et al. 2011, Hendricks 2012, Ingersoll et al. 2013).

Additional information is needed to identify the distribution and location of caves used as bat hibernacula in western North America (Nagorsen et al. 1993, Olson et al. 2011, Hendricks 2012). Furthermore, long-term changes in regional populations of bats remain poorly understood in this area (Knudsen et al. 2013, Weller et al. 2014). Previous short-term studies, as well as mist netting and current acoustic sampling, have documented the importance of caves on the Snake River Plain in southern Idaho as predominant hibernacula for Townsend's big-eared bats (Corynorhinus townsendii townsendii), western small-footed myotis (Myotis ciliolabrum ssp.), and, to a much lesser extent, big brown bats (Eptesicus fuscus) (Genter 1986, Wackenhut 1990, Doering 1996, Gillies et al. 2014). For many bat species, caves that are used as hibernacula are a limited resource, which is why the identification and conservation of these areas is one of the most important topics in bat conservation (O'Shea et al. 2003, Perry 2013, Lee et al. 2015).

Some caves on the Snake River Plain have been identified as important locations for win- tering bats (Genter 1986), but $>650$ caves exist in this area and it is important to identify which of those caves are of greatest conservation priority (Gillies et al. 2014, Slocum et al. 2016). A recent study investigated the hibernaculum characteristics of lava-tube caves in southern Idaho (Gillies et al. 2014). A comprehensive summary of hibernacula on the Snake River Plain, however, has not been conducted since the mid-1990s (Pierson et al. 1999). Both of these documents focused on Townsend's big-eared bats (Pierson et al. 1999, Gillies et al. 2014); little is known about other species using caves in this area as hibernacula.

With the arrival of white-nose syndrome in the state of Washington, adjacent to Idaho in the western United States (Lorch et al. 2016), it is critical to understand the use of caves by other species, then to prioritize monitoring of those caves for the arrival of this disease (Reeder et al. 2016, IDFG 2017, Neubaum et al. 2017). We compiled data on counts of hibernating bats across 32 years in 64 caves on the Snake River Plain in southern Idaho, USA, to identify the distribution and location of important bat hibernacula. Our results can guide biologists in prioritizing caves to sample for the arrival of white-nose syndrome and help guide management and conservation of bats and their habitat, as well as aid in landuse planning in this area.

\section{Methods \\ Study Area}

We conducted internal surveys and compiled counts of hibernating bats in caves located on the Snake River Plain in southern Idaho (Genter 1986) (ftp://ftp.epa.gov/wed/eco regions/us/Eco_Level_III_US.pdf). We and others surveyed caves in the following counties: Bingham, Blaine, Bonneville, Butte, Clark, Fremont, Gooding, Lincoln, Minidoka, and Power. Caves on the Snake River Plain were formed from tubes of molten basaltic lava flows or from lava blisters produced by pockets of trapped gas that were uncovered when cave ceilings collapsed (Mullican and Carraway 1990, Wackenhut 1990, Gillies et al. 2014). None of the caves are solution or limestone caves (Wackenhut 1990, Doering 1996). Cave lengths in our study area varied from $25 \mathrm{~m}$ to $2.1 \mathrm{~km}$, and ceiling height ranged from $\sim 25 \mathrm{~cm}$ to $>10 \mathrm{~m}$ (Wackenhut 1990, Earl and Morris 
1995). Average temperature and relative humidity in 7 caves used as hibernacula in our study area were $2.2{ }^{\circ} \mathrm{C}\left(\mathrm{SE} 0.54{ }^{\circ} \mathrm{C}\right)$ and $84.5 \%$ (SE $3.7 \%$ ), respectively (Gillies et al. 2014). Caves in our study area are located in cold desert consisting mainly of sagebrush (Artemisia tridentata ssp.) steppe vegetation (Reynolds et al. 1986, Nelle et al. 2000, Gillies et al. 2014) and range in elevation from $1053 \mathrm{~m}$ to $1875 \mathrm{~m}$ (Genter 1986, Mullican and Carraway 1990, Wackenhut 1990).

The caves we surveyed were located on land managed by the National Park Service (i.e., Craters of the Moon National Monument and Preserve), the Bureau of Land Management, and the U.S. Department of Energy, Idaho Operations Office (DOE-ID). The DOE-ID owns the Idaho National Laboratory site, which was established in the 1940s by the U.S. Atomic Energy Commission as the National Reactor Testing Station, and the site has been closed to the public since that time (Reynolds et al. 1986). In all other areas, 7 caves were gated and 8 caves had seasonal restrictions limiting public access. All other caves were accessible to the public, though 2 caves were on private land.

Weather patterns in our study area were characterized by hot, dry summers and cold winters (Genter 1986, Reynolds et al. 1986, Wackenhut 1990). Most of the precipitation occurred during the winter as snow and during the spring as rain or snow (Reynolds et al. 1986, Wackenhut 1990). We produced a climograph to determine general seasons (sensu Bowyer et al. 1998, Whiting et al. 2008), plotting precipitation against temperature from 1984 to 2013 using data from 4 weather stations across the extent of our study area (Shoshone $1 \mathrm{WNW}$, Aberdeen Experiment Station, St. Anthony 1 WNW, and Idaho Falls 46 W; Western Regional Climate Center, http://www.wrcc.dri.edu/). Four general seasons were evident in our study area: spring (April-June), summer (July-September), autumn (October, a transitional month), and winter (November-March). From 1984 to 2013 the average monthly temperature in winter while bat counts occurred was $-3{ }^{\circ} \mathrm{C}$ $\left(\right.$ SD $3.8^{\circ} \mathrm{C}$ ), and the average monthly snowfall was $111 \mathrm{~mm}$ (SD $54.2 \mathrm{~mm}$ ). Bats in our study area generally entered caves to hibernate in late October and remained in caves until early April (Keller et al. 1993, Bosworth 1994, Doering 1996). Names of caves in this manuscript have been replaced with a letter and number combination to minimize revealing cave locations, which can lead to destruction of bats and hibernacula (Sheffield et al. 1992).

\section{Data Collection}

We compiled and vetted count records of hibernating colonies of bats from a journal publication ( $n=5$; Genter 1986), theses $(n=$ 17; Wackenhut 1990, Bosworth 1994), a university report ( $n=6$; Keller et al. 1993), surveys that were conducted by the authors of this paper $(n=85)$, and records and reports $(n=$ 191) archived with the Bureau of Land Management, DOE-ID, and Craters of the Moon National Monument and Preserve. We only used counts of hibernating colonies that were conducted during the winter (1 November31 March) (Perkins et al. 1990, Nagorsen et al. 1993, Szewczak et al. 1998). Areas passable by researchers in each cave were surveyed in the same general area each year. The mean number of investigators who entered a cave to conduct counts of bats in hibernacula was 3 (SD 1.2, range 1-8 investigators, number of counts $=267$ ). Investigators identified and counted bats (Szewczak et al. 1998, Kuenzi et al. 1999, Wainwright and Reynolds 2013) and used care to minimize disturbing hibernating bats when conducting surveys (Sheffield et al. 1992, Sikes et al. 2011, Wainwright and Reynolds 2013). The mean number of surveys in each cave was 5 (SD 3.5 surveys, range 1-14).

We considered a cave to be a hibernaculum if $\geq 2$ bats were observed in at least one survey. During hibernacula surveys, 14 caves were visited $\geq 2$ times in the same year (Genter 1986, Wackenhut 1990, Keller et al. 1993, Bosworth 1994). In those instances, we used the highest count of a species observed during the winter in those years; therefore, high counts for different species may not have occurred on the same survey date.

We considered a cave biologically important for Townsend's big-eared bats in our study area if $\geq 20$ individuals were counted in a cave during any year of surveys. This criterion was based on the facts that this species roosts gregariously, swarms before hibernation, is an obligatory hibernator, and is a special status species (Neubaum et al. 2017). Our criterion was supported by the observation that across the western United States few Townsend's big-eared bats ( $<20$ individuals) hibernate in any given cave (Twente 1960, 
Kunz and Martin 1982, Perkins et al. 1990, Nagorsen et al. 1993, Szewczak et al. 1998, Kuenzi et al. 1999, Pierson et al. 1999, Sherwin et al. 2000, Adams 2003, Hayes et al. 2011, Hendricks 2012), although exceptions exist (Safford 1989, Jagnow 1998, Weller et al. 2014).

Likewise, we considered a cave biologically important for western small-footed myotis if $\geq 5$ individuals were observed in a cave during any year of surveys. This designation was based on the facts that this species also roosts gregariously, swarms before hibernation, is an obligatory hibernator, and is a special status species (Neubaum et al. 2017). This criterion was supported because western small-footed myotis hibernate in small numbers (1-6 individuals) in the western United States (Twente 1960, Perkins et al. 1990, Kuenzi et al. 1999, Holloway and Barclay 2001), although exceptions exist (Safford 1989, Jagnow 1998).

One primary criterion from Neubaum et al. (2017) for designating a biologically important cave is that a loss of bats at the cave would affect $>5 \%$ of the bat population in the area. We only visited a small number of caves used by bats in winter in our study area. Therefore, we could not estimate if bats in our study caves comprised $>5 \%$ of the population. However, based on our long-term local knowledge of hibernating bats in caves that are accessible to survey, we determined that a loss of $\geq 20$ Townsend's big-eared bats and $\geq 5$ western small-footed myotis in a cave should cause alarm and prompt local biologists to management concern and action.

Counting Townsend's big-eared bats is an effective way to estimate the number of individuals in hibernacula because these bats often occupy open and exposed areas in caves during hibernation (Alcorn 1944, Genter 1986, Wackenhut 1990). These mammals have long ears that are curled like a ram's horn or are sometimes unfurled, which facilitates identification of these bats during hibernation (Humphrey and Kunz 1976, Genter 1986, Jagnow 1998). Additionally, Townsend's big-eared bats can use the same cave across years for hibernation (Twente 1955, Humphrey and Kunz 1976, Wackenhut 1990, Sherwin et al. 2003). In our study area, for example, $95 \%$ of 224 banded individuals that were relocated the year after they were banded had returned to the cave in which they were captured and banded (Wackenhut 1990). We recognize that during our surveys the number of western small-footed myotis was likely underestimated (Safford 1989) because bats of this species may wedge themselves into cracks or crevices when hibernating and may not be easily visible to researchers (Genter 1986, Perkins et al. 1990, Nagorsen et al. 1993, Holloway and Barclay 2001).

\section{Results}

From 1984 to 2016, researchers conducted 304 surveys in 64 caves. During those surveys, investigators counted 37,693 bats; the predominant species were Townsend's bigeared bat $(36,237$ individuals or $96.1 \%$ of bats counted) and western small-footed myotis (1432 individuals or $3.8 \%$ of bats counted). Townsend's big-eared bats used 58 caves (91\% of caves surveyed) and western smallfooted myotis used 22 caves (34\% of caves surveyed). Biologists also documented 4 big brown bats, 8 little brown myotis (Myotis lucifugus), 2 Yuma myotis (Myotis yumanensis), and 10 long-eared myotis (Myotis evotis) in 4 hibernacula.

Thirty of the 64 caves $(47 \%$ of caves surveyed) were biologically important (maximum count $\geq 20$ individuals) for Townsend's bigeared bats (Fig. 1); the largest hibernating colony of this mammal occupied cave C34 (number of surveys $=8, \bar{x}=1610$ individuals, SD 415, range 962-1994 individuals). The most recent count in cave C34 was 1932 Townsend's big-eared bats in February 2015. Thirteen of the 64 caves (20\% of caves surveyed) were biologically important (maximum count $\geq 5$ individuals) for western small-footed myotis (Fig. 2); the largest hibernating colony of this mammal in those 13 caves occupied cave C24 (number of surveys $=6, \bar{x}=98$ individuals, SD 53, range 32-152 individuals). The most recent count in cave C24 was 152 western small-footed myotis in March 2016, although some of those individuals may have been little brown myotis. Ten caves were biologically important hibernacula for both Townsend's big-eared bats and western smallfooted myotis (C1, C27, C30, C34, C39, C40, C49, C52, C54, and C60). The highest diversity of bats was observed in cave C1 (Townsend's big-eared bats, western smallfooted myotis, little brown myotis, and longeared myotis). The only other caves in which 

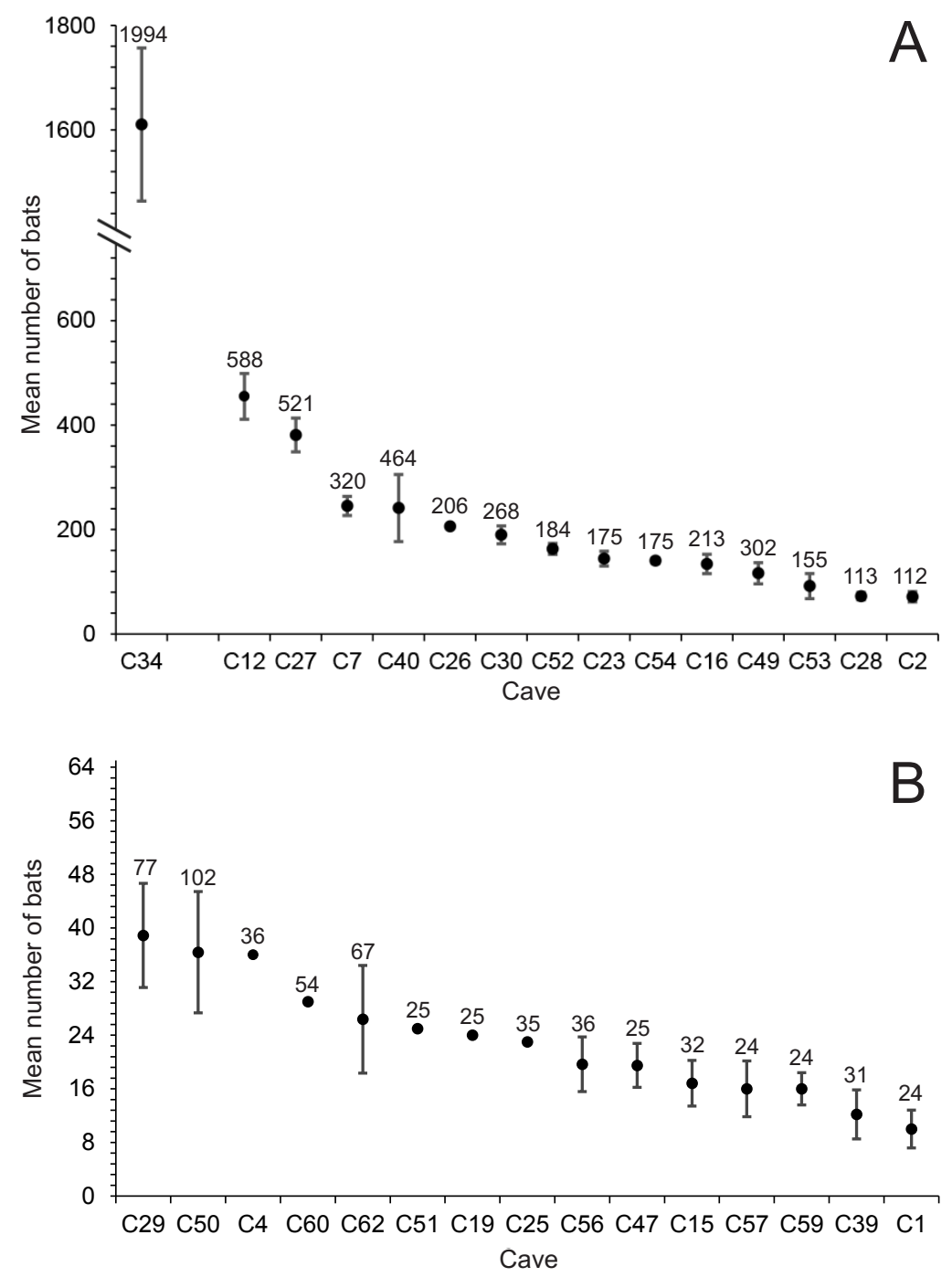

Fig. 1. Mean number $( \pm \mathrm{SE})$ of Townsend's big-eared bats (Corynorhinus townsendii townsendii) during winter surveys in 30 lava-tube caves with a maximum count of $>105$ bats (A) or a maximum count of $<105$ bats (B) on the Snake River Plain in southern Idaho, USA, from 1984 to 2016. Only caves with a maximum count of $\geq 20$ Townsend's big-eared bats were included in this figure. The high count for each cave is indicated by the number above the error bars. If error bars are not visible, they are contained within the symbol.

we observed $>2$ species of bats were C40 and C54: Townsend's big-eared bats, western small-footed myotis, and big brown bats were observed in both caves.

\section{Discussion}

Sixty-four monitored caves were used as hibernacula by 6 species of bats on the Snake River Plain in southern Idaho, USA. Fiftyeight of those caves were used by Townsend's big-eared bats and 22 caves were used by western small-footed myotis. Based on bat capture and other research at some of our study caves, Townsend's big-eared bats and western small-footed myotis are 2 of the most common bats in our study area in the summer (Wackenhut 1990, Keller and Saathoff 1996, Haymond and Rogers 1998) and the winter (Genter 1986, Gillies et al. 2014, IDFG 2017). Other bat species are not as frequently documented in the summer in our study area, and 


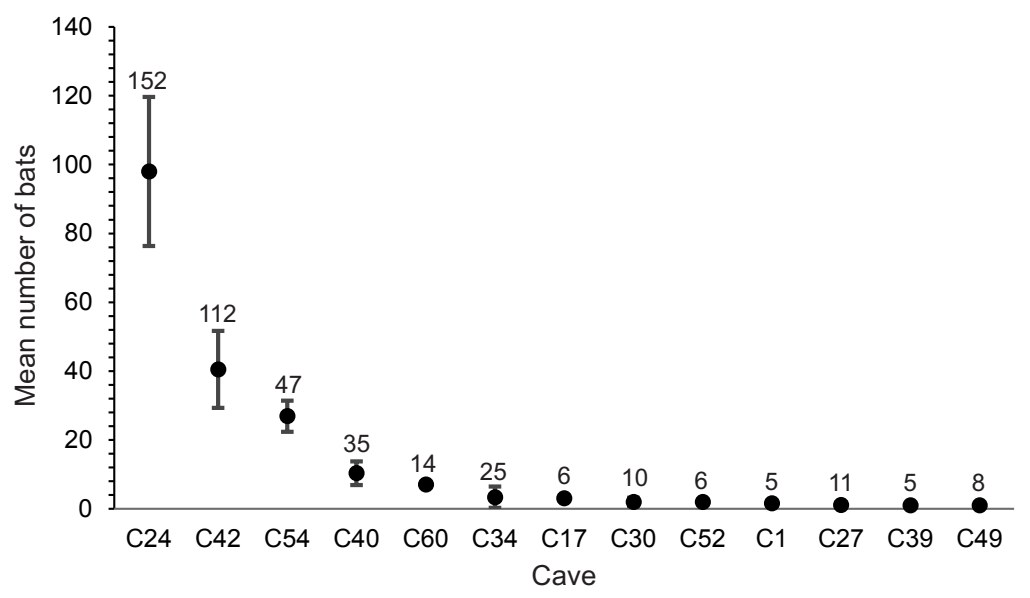

Fig. 2. Mean number $( \pm \mathrm{SE})$ of western small-footed myotis (Myotis ciliolabrum ssp.) during winter surveys in 13 lavatube caves on the Snake River Plain in southern Idaho, USA, from 1984 to 2016 . Caves with a maximum count of $\geq 5$ western small-footed myotis were included in this figure. A survey in 2016 documented potential little brown myotis (Myotis lucifugus) in cave C24. The high count for each cave is indicated by the number above the error bars. If error bars are not visible, they are contained within the symbol.

we know very little about where those species hibernate. The lack of other species hibernating in our study area may be a function of the following: low abundance of those species, movement of bats to other areas to hibernate, low detectability of bats in the caves we surveyed because these species hibernate in rock fall and crevices, or use of other structures for hibernation.

In general across diverse areas in the western United States, Townsend's big-eared bats were absent from surveyed mines and caves or they used these features in small numbers (Twente 1960, Perkins et al. 1990, Szewczak et al. 1998, Hayes et al. 2011). Townsend's bigeared bats occur in low densities across most of their range (Humphrey and Kunz 1976, Kunz and Martin 1982, Sherwin et al. 2003, Gruver and Keinath 2006), and populations of this species in areas outside of Idaho may be limited by roosting sites if caves and other suitable hibernacula such as mines and rock crevices are not available (Pearson et al. 1952, Pierson et al. 1999). Our results indicate that Townsend's big-eared bat is the predominant species that hibernates on the Snake River Plain in southern Idaho, and that this area has a high density of hibernacula for Townsend's big-eared bats and western small-footed myotis. Additionally, this area has $>650$ lava caves (Genter 1986, Wackenhut 1990, Gillies et al. 2014). Undoubtedly, more caves are used as hibernacula in our study area than we have identified (Genter 1986, Wackenhut 1990, Gillies et al. 2014), further highlighting the importance of the Snake River Plain of southern Idaho for the conservation and management of Townsend's big-eared bats and western smallfooted myotis in western North America.

We considered 30 caves in our study area as biologically important for Townsend's bigeared bats. The largest hibernating colony of this species occupied cave C34, in which our highest count was 1994 bats. Across the revised distribution of C. $t$. townsendii (Piaggio and Perkins 2005), usually only a few individuals ( $<20$ bats) of this species are counted in caves during the winter (Alcorn 1944, Twente 1960, Nagorsen et al. 1993, Szewczak et al. 1998, Kuenzi et al. 1999, Pierson et al. 1999, Hendricks 2012). One exception is Jewel Cave in South Dakota (Jones and Genoways 1967, Turner and Jones 1968, Humphrey and Kunz 1976, Choate and Anderson 1997); the hibernating colony of Townsend's big-eared bats in Jewel Cave, however, has decreased from 4000 individuals before 1959 to 853 individuals as of 2000 (Ellison et al. 2003). Townsend's big-eared bats are a species of conservation concern (Adams 2003, O'Shea et al. 2003, Gruver and Keinath 2006, Hayes et al. 2011). Our results indicate that the Snake River Plain has one of the highest densities of biologically important hibernacula in caves for 
Townsend's big-eared bats in the western distribution of this subspecies, as well as one of the largest-if not the largest-hibernaculum (cave C34) for this subspecies in western North America.

Western small-footed myotis are common in arid deserts of western North America; however, little is known about population numbers of this species (Holloway and Barclay 2001, Ellison et al. 2003). These bats generally hibernate in small numbers (1-6 individuals; Twente 1960, Perkins et al. 1990, Nagorsen et al. 1993, Szewczak et al. 1998, Kuenzi et al. 1999, Hendricks 2012), but large colonies of western small-footed myotis do occur in New Mexico (111 individuals; Jagnow 1998) and in South Dakota (20 individuals; Choate and Anderson 1997). In our study, we documented a relatively high density of biologically important hibernacula in caves for western small-footed myotis. Additionally, caves C24 and C42 are 2 of the largest documented hibernacula in western North America for this species. Wintering populations of Myotis spp. are more likely to become infected with white-nose syndrome than other species (Wilder et al. 2011, Hendricks 2012), and general conditions of humidity and temperature exist for the growth of Pseudogymnoascus destructans (the fungus that causes white-nose syndrome) in caves in southern Idaho (Knudsen et al. 2013, Gillies et al. 2014). White-nose syndrome is now documented in Washington, USA (Lorch et al. 2016), so monitoring hibernacula in Idaho is needed to understand the potential spread of this disease (Reeder et al. 2016, IDFG 2017, Neubaum et al. 2017). Therefore, we recommend that consistent monitoring for whitenose syndrome occur at the 13 biologically important hibernacula for western small-footed myotis in our study area.

In our study area, 10 caves were biologically important for both Townsend's big-eared bats and western small-footed myotis. Oftentimes hibernaculum surveys across large areas are subject to constraints such as limited funding, difficult logistics, and shifting conservation priorities among agencies. These constraints cause intermittent surveys and unequal monitoring effort across years (Ellison et al. 2003, Ingersoll et al. 2013, Weller et al. 2014). Because white-nose syndrome is in the western United States (Lorch et al. 2016) and because it is important to continually monitor the abundance of Townsend's big-eared bats in southern Idaho (IDFG 2017), if the aforementioned issues arise in our study area, we recommend that the 10 hibernacula used by both Townsend's big-eared bats and western small-footed myotis be prioritized for monitoring (Reeder et al. 2016, IDFG 2017). We maintain, however, that it is important to monitor caves used by small numbers of bats as well; decreases in the number or elimination of bats in these caves can indicate more subtle declines in species across large geographic areas. We hypothesize that the 10 caves used by both Townsend's big-eared bats and western small-footed myotis are most likely used by other bat species as well. We therefore recommend that biologists use acoustic equipment to identify the species diversity of bats at those 10 caves.

White-nose syndrome and wind energy facilities have emerged in the past decade as unprecedented threats to bat populations in North America (Blehert et al. 2009, Cryan 2011, Foley et al. 2011). Additionally, the loss, modification, and disturbance of hibernacula by humans are pressing concerns for bat populations (Kunz and Martin 1982, Wackenhut 1990, Pierson et al. 1999, Adams 2003). Knowledge regarding most populations of bats in the western United States is limited (Genter 1986, Adams 2003, Knudsen et al. 2013), and protecting hibernacula is a main concern for the conservation of bats in this region (Sheffield et al. 1992, Adams 2003, Ingersoll et al. 2010). We documented one of the largest densities of caves used by hibernating Townsend's bigeared bats and western small-footed myotis in western North America, as well as possibly the largest reported hibernaculum for each of those species in western North America. Our data underscore the importance of the Snake River Plain for hibernating Townsend's bigeared bats and western small-footed myotis. Our results will guide biologists in prioritizing caves to sample for the arrival of white-nose syndrome and help guide the management and conservation of bats and their habitat as well as aid in land-use planning in this area.

\section{ACKNOWLEDGMENTS}

We thank employees of Wastren Advantage, the Idaho Department of Fish and Game, the National Park Service, and the 
Bureau of Land Management for help with collecting data. We also thank the U.S. Department of Energy, Idaho Operations Office at the Idaho National Laboratory for funding bat monitoring (contract number DENE0008477). Many employees and volunteers of the preceding organizations have helped with cave surveys since 1984 . We also thank B. Abel, D. Halford, and B. Holmes for reviewing an earlier version of this manuscript.

\section{Literature Cited}

ADAms, R.A. 2003. Bats of the Rocky Mountain West: natural history, ecology, and conservation. University Press of Colorado, CO. 328 pp.

AlCORN, J.R. 1944. Notes on the winter occurrence of bats in Nevada. Journal of Mammalogy 25:308-310.

Arnett, E.B., W.K. Brown, W.P. Erickson, J.K. Fiedler, B.L. Hamilton, T.H. Henry, A. Jain, G.D. Johnson, J. Kerns, AND R.R. Koford, ET AL. 2008. Patterns of bat fatalities at wind energy facilities in North America. Journal of Wildlife Management 72:61-78.

Blehert, D.S., A.C. Hicks, M. Behr, C.U. Meteyer, B.M. Berlowski-Zier, E.L. Buckles, J.T.H. Coleman, S.R. Darling, A. Gargas, and R. Niver, et al. 2009. Bat white-nose syndrome: an emerging fungal pathogen? Science 323:227.

Bosworth, W.R. 1994. Characteristics of winter activity in Plecotus townsendii in southeastern Idaho. Master's thesis, Idaho State University, Pocatello, ID.

Bowyer, R.T., V. Van Ballenberghe, and J.G. Kie. 1998. Timing and synchrony of parturition in Alaskan moose: long-term versus proximal effects of climate. Journal of Mammalogy 79:1332-1344.

Choate, J.R., and J.M. Anderson. 1997. Bats of Jewel Cave National Monument, South Dakota. Prairie Naturalist 29:39-47.

Cryan, P.M. 2011. Wind turbines as landscape impediments to the migratory connectivity of bats. Environmental Law 41:355-370.

Cryan, P.M., and R.M.R. Barclay. 2009. Causes of bat fatalities at wind turbines: hypotheses and predictions. Journal of Mammalogy 90:1330-1340.

Doering, R.W. 1996. Thermal implications of roost site selection in hibernating Plecotus townsendii. Master's thesis, Idaho State University, Pocatello, ID.

EARL, S., AND R.C. Morris. 1995. A survey of 14 caves on the Idaho National Engineering Laboratory. Report ESRF-006, Idaho Falls, ID.

Ellison, L.E., T.J. O’Shea, M.A. Bogan, A.L. Everette, AND D.M. SChNEIDER. 2003. Existing data on colonies of bats in the United States: summary and analysis of the U.S. Geological Survey's Bat Population Database. Pages 127-237 in T.J. O'Shea and M.A. Bogan, editors, Monitoring trends in bat populations of the United States and territories: problems and prospects. U.S. Geological Survey, Biological Resources Division.

Foley, J., D. Clifford, K. Castle, P. Cryan, and R.S. OSTFELD. 2011. Investigating and managing the rapid emergence of white-nose syndrome, a novel, fatal, infectious disease of hibernating bats. Conservation Biology 25:223-231.
Genter, D.L. 1986. Wintering bats of the upper Snake River Plain: occurrence in lava-tube caves. Great Basin Naturalist 46:241-244.

Gillies, K.E., P.J. Murphy, and M.D. MatocQ. 2014. Hibernacula characteristics of Townsend's big-eared bats in southeastern Idaho. Natural Areas Journal 34:24-30.

Gruver, J.C., AND D.A. Keinath. 2006. Townsend's bigeared bat (Corynorhinus townsendii): a technical conservation assessment. USDA Forest Service, Rocky Mountain Region.

Hayes, M.A., R.A. SchorR, AND K.W. Navo. 2011. Hibernacula selection by Townsend's big-eared bat in southwestern Colorado. Journal of Wildlife Management 75:137-143.

Haymond, S., and D.S. Rogers. 1998. Habitat use by summer populations of bats in sagebrush-steppe. Report ESRF-027, Department of Energy, Idaho Falls, ID.

HENDRICKS, P. 2012. Winter records of bats in Montana. Northwest Naturalist 93:154-162.

Holloway, G.L., AND R.M.R. BARCLAY. 2001. Myotis ciliolabrum. Mammalian Species 670:1-5.

Humphrey, S.R., and T.H. KunZ. 1976. Ecology of a Pleistocene relict, the western big-eared bat (Plecotus townsendii), in the southern Great Plains. Journal of Mammalogy 57:470-494.

[IDFG] Idaho Department of Fish and Game. 2017. Idaho State Wildlife Action Plan, 2015. Idaho Department of Fish and Game, Boise, ID. Grant No. F14AF01068 Amendment \#1, Sponsored by the U.S. Fish and Wildlife Service, Wildlife and Sport Fish Restoration Program. http://fishandgame.idaho.gov

Ingersoll, T.E., K.W. NaVo, and P. DE Valpine. 2010. Microclimate preferences during swarming and hibernation in the Townsend's big-eared bat, Corynorhinus townsendii. Journal of Mammalogy 91:1242-1250.

Ingersoll, T.E., B.J. Sewall, and S.K. Amelon. 2013. Improved analysis of long-term monitoring data demonstrates marked regional declines of bat populations in the eastern United States. PLOS ONE 8: e65907.

JAGNOW, D.H. 1998. Bat usage and cave management of Torgac Cave, New Mexico. Journal of Cave and Karst Studies 60:33-38.

Jones, J.K., AND H.H. Genoways. 1967. Annotated checklist of bats fron South Dakota. Transactions of the Kansas Academy of Science 70:184-196.

Keller, B.L., W.R. Bosworth, and R.W. Doering. 1993. Final technical report: bat habitat research. Report DOE/ID/13142_T1, United States Department of Energy, Pocatello, ID.

Keller, B.L., AND R.T. SAathoff. 1996. A netting survey of water and cave areas used by bats at Craters of the Moon National Monument, Butte County, Idaho. Idaho State University, ID.

Knudsen, G.R., R.D. Dixon, and S.K. Amelon. 2013. Potential spread of white-nose syndrome of bats to the Northwest: epidemiological considerations. Northwest Science 87:292-306.

Kuenzi, A.J., G.T. Downard, and M.L. Morrison. 1999. Bat distribution and hibernacula use in west central Nevada. Great Basin Naturalist 59:213-220.

KunZ, T.H., and R.A. Martin. 1982. Plecotus townsendii. Mammalian Species 175:1-6.

Lee, D.N., R.C. StakK, W.L. Puckette, M.J. Hamilton, D.M. Leslie, and R.A. Van Den Bussche. 2015. 
Population connectivity of endangered Ozark bigeared bats (Corynorhinus townsendii ingens). Journal of Mammalogy 96:522-530.

Lorch, J.M., J.M. Palmer, D.L. Lindner, A.E. Ballmann, K.G. George, K. Griffin, S. Knowles, J.R. Huckabee, K.H. Haman, C.D. Anderson, P.A. Becker, J.B. Buchanan, J.T. Foster, and D.S. Blehert. 2016. First detection of bat white-nose syndrome in western North America. mSphere 1(4):e00148-16.

Maher, S.P., A.M. Kramer, J.T. Pulliam, M.A. Zokan, S.E. Bowden, H.D. Barton, K. Magori, and J.M. DRAKE. 2012. Spread of white-nose syndrome on a network regulated by geography and climate. Nature Communications 3:1306.

Mullican, T.R., and L.N. Carraway. 1990. Shrew remains from Moonshiner and Middle Butte Caves, Idaho. Journal of Mammalogy 71:351-356.

Nagorsen, D.W., A.A. Bryant, D. Kerridge, G. Roberts, A. Roberts, and M.J. Sarell. 1993. Winter bat records for British Columbia. Northwestern Naturalist 74:61-66.

Nelle, P.J., K.P. Reese, And J.W. Connelly. 2000. Longterm effects of fire on sage grouse habitat. Journal of Range Management 53:586-591.

Neubaum, D.J., K.W. Navo, and J.L. Siemers. 2017. Guidelines for defining biologically important bat roosts: a case study from Colorado. Journal of Fish and Wildlife Management 8:272-282

O'Shea, T.J., M.A. Bogan, and L.E. Ellison. 2003. Monitoring trends in bat populations of the United States and territories: status of the science and recommendations for the future. Wildlife Society Bulletin 31:16-29.

Olson, C.R., D.P. Hobson, and M.J. Pybus. 2011. Changes in population size of bats at a hibernaculum in Alberta, Canada, in relation to cave disturbance and access restrictions. Northwestern Naturalist 92: 224-230.

Pearson, O.P., M.R. Koford, and A.K. Pearson. 1952. Reproduction of the lump-nosed bat (Corynorhinus rafinesquei) in California. Journal of Mammalogy 33:273-320.

Perkins, J.M., J.M. Barss, and J. Peterson. 1990. Winter records of bats in Oregon and Washington. Northwestern Naturalist 71:59-62.

PerRY, R.W. 2013. A review of factors affecting cave climates for hibernating bats in temperate North America. Environmental Reviews 21:28-39.

Piaggio, A.J., and S.L. Perkins. 2005. Molecular phylogeny of North American long-eared bats (Vespertilionidae: Corynorhinus); inter- and intraspecific relationships inferred from mitochondrial and nuclear DNA sequences. Molecular Phylogenetics and Evolution 37:762-775.

Pierson, E.D., M.C. Wackenhut, J.S. Altenbach, P. Bradley, P. Call, D.L. Genter, C.E. Harris, B.L. Keller, B. Lengus, L. Lewis, et AL. 1999. Species conservation assessment and strategy for Townsend's big-eared bat (Corynorhinus townsendii townsendii and Corynorhinus townsendii pallescens). Idaho Conservation Effort, Idaho Dept. of Fish and Game, Boise.

Reeder, D.M., K.A. Field, and M.H. Slater. 2016. Balancing the costs of wildlife research with the benefits of understanding a panzootic disease, white-nose syndrome. ILAR Journal 56:275-282.

Reynolds, T.D., J.W. Connelly, D.K. HaLford, AND W.J. ARTHUR. 1986. Vertebrate fauna of the Idaho
National Environmental Research Park. Great Basin Naturalist 46:513-527.

SAFFord, M. 1989. Bat population study of Fort Stanton Cave. The NSS Bulletin: Quarterly Journal of the National Speleological Society 51:42-46.

Sheffield, S.R., J.H. Shaw, G.A. Heidt, and L.R. McClenaghan. 1992. Guidelines for the protection of bat roosts. Journal of Mammalogy 73:707-710.

Sherwin, R.E., W.L. Gannon, and J.S. Altenbach. 2003. Managing complex systems simply: understanding inherent variation in the use of roosts by Townsend's big-eared bat. Wildlife Society Bulletin 31:62-72.

Sherwin, R.E., D. Stricklan, and D.S. Rogers. 2000. Roosting affinities of Townsend's big-eared bat (Corynorhinus townsendii) in northern Utah. Journal of Mammalogy 81:939-947.

Sikes, R.S., W.L. Gannon, and the American Soceity OF Mammalogists. 2011. Guidelines of the American Society of Mammalogists for the use of wild mammals in research. Journal of Mammalogy 92: 235-253.

Slocum, K., T. Stefanic, and T.J. Rodhouse. 2016. Bat hibernacula surveys in Craters of the Moon National Monument and Preserve: 2016 status report. Unpublished report on file at Craters of the Moon National Monument and Preserve. National Park Service.

SzewcZaK, J.M., S.M. SzewcZaK, M.L. Morrison, and L.S. HALL. 1998. Bats of the White and Inyo Mountains of California-Nevada. Great Basin Naturalist 58:66-75.

Turner, R.W., AND J.K. JonEs. 1968. Additional notes on bats from western South Dakota. Southwestern Naturalist 13:444-447.

TwEnTE, J.W. 1955. Aspects of a population study of caverndwelling bats. Journal of Mammalogy 36:379-390.

Twente, J.W. 1960. Environmental problems involving the hibernation of bats in Utah. Utah Academy Proceedings 37:67-71.

WaCKenhut, M.C. 1990. Bat species overwintering in lava-tube caves in Lincoln, Gooding, Blaine, Bingham, and Butte Counties, Idaho with special reference to annual return of banded Plecotus townsendii. Master's thesis, Idaho State University, Pocatello, ID.

Wainwright, J.M., and N.D. Reynolds. 2013. Cave hibernaculum surveys of a Townsend's big-eared bat (Corynorhinus townsendii) colony at Mount St. Helens, Washington. Northwestern Naturalist 94: $240-244$.

Weller, T.J., S.C. Thomas, and J.A. Baldwin. 2014. Use of long-term opportunistic surveys to estimate trends in abundance of hibernating Townsend's big-eared bats. Journal of Fish and Wildlife Management 5: $59-69$.

Whiting, J.C., R.T. Bowyer, and J.T. Flinders. 2008. Young bighorn (Ovis canadensis) males: can they successfully woo females? Ethology 114:32-41.

Wilder, A.P., W.F. Frick, K.E. Langwig, and T.H. Kunz. 2011. Risk factors associated with mortality from white-nose syndrome among hibernating bat colonies. Biology Letters 7:950-953.

Received 28 February 2017 Revised 6 January 2018

Accepted 26 February 2018

Published online 19 July 2018 